\title{
Benthos of Lake Orta in the year 1996
}

\author{
Renato BAUDO*, Anna OCCHIPINTI ${ }^{1)}$, Anna Maria NOCENTINI and Monica SABOLLA \\ CNR Istituto Italiano di Idrobiologia, Largo V. Tonolli 50, 28922 Verbania Pallanza, Italy \\ ${ }^{1)}$ Dipartimento di Genetica e Microbiologia, Sezione Ecologia, Via Sant'Epifanio 14, 27100 Pavia, Italy \\ *e-mail corresponding author: r.baudo@iii.to.cnr.it
}

\begin{abstract}
Lake Orta has been interested since 1926 by severe industrial pollution, due to the effluents of a rayon (artificial silk) factory that discharged huge amounts of copper and ammonia. As a consequence, the benthic fauna faced noticeable changes, becoming extremely poor in species. However, after extensive liming (in 1989-90), the biotic communities of the lake showed many signs of recovery, and in 1996 it was decided to study the benthos composition and abundance in detail, to assess whether the lake restoration resulted in a complete recovery of this biotic compartment. Actually, both the small number of taxa, and the low abundance of the benthos, indicate that the sedimentary environment is still very stressed. In fact, albeit this study shows that benthos fauna is actively recolonising Lake Orta bottom, spreading from river mouths, in 1996 the benthic community cannot be considered fully organised.
\end{abstract}

Key words: benthos, sediment contamination, Lake Orta, Northern Italy

\section{INTRODUCTION}

Lake Orta is well known to have been interested since 1926 by severe industrial pollution, due to the effluents of a rayon (artificial silk) factory that discharged huge amounts of copper and ammonia. The evolution of the lake chemical conditions and the quick decline of the planktonic communities have been well documented by several studies, and are summarised in other papers of this monograph (Calderoni \& Tartari 2001; Bonacina et al. 2001). Therefore, in this paper it will be only mentioned that, after the onset of pollution, the contamination soon interested also sediments (Baudo \& Beltrami 2001), and, as a consequence, also Lake Orta benthos faced noticeable changes.

From the few studies from pre-industrial times, it is known that the benthic fauna of this lake hosted at least Tardigrada, Nematoda, Oligochaeta (Parona 1880), Mollusca Lamellibranchia (Monti 1930), and Turbellaria (Colosi 1924).

After the start of the pollution, however, the littoral benthic fauna became extremely poor in species, molluscs were completely absent (Moretti 1954a, b), and samples from the deep bottoms were completely devoid of both micro- and macrofauna (Corbella et al. 1958).

In the 1960s, an improvements in the treatment of the silk factory effluents allowed a partial recolonisation of the littoral zone by Oligochaeta, Chironomidae and Tricoptera (Oioli 1969); Protozoa, Rotifera and one species of Cyclops were found in the profundal zone (Ruggiu 1969); by the 1980s a benthic community, albeit unstable, was established at least in some part of the lake (Bonacina et al. 1986; Bonacina et al. 1988; Cattaneo 1992).

In 1989-1990, Lake Orta was treated with $14,500 \mathrm{t}$ of limestone (Calderoni et al. 1991), starting the resto- ration of the lake, and also the littoral fauna (Ballarè et al. 1992) as well as the plankton, quickly responded to the treatment, showing a good recovery both in size and quality.

In order to document the evolution of the sedimentary conditions, in 1996 a new research was started, and the results obtained to assess the extent of the sediment recolonisation, are reported here.

\section{MATERIAL AND METHODS}

Samples of sediments were taken in 51 stations (Fig. 1) in July 1996 by means of a Ponar grab that covers an area of $420 \mathrm{~cm}^{2}$ and collects a sediment layer $10-15 \mathrm{~cm}$ thick (depending on the sediment compaction). The samples were then fixed with $10 \%$ neutralised formaldehyde. In the lab, animals were sieved through a series of sieves $(5,2,0.9,0.5,0.355$, and $0.28 \mathrm{~mm}$ mesh sizes), then visually counted (under a stereomicroscope for smaller animals, after staining with Bengale Rose if needed), and identified (to species or other taxonomic level) after mounting on Faure liquid. For Oligochaeta, the identification was based on the Sperber (1952) and Brinkhurst \& Jamieson (1971) classifications. For Chironomidae, on keys provided by Rossaro (1982), Ferrarese (1983), Wiederholm (1983, 1986), and Nocentini (1985). For other taxa, on keys by Reynoldson (1978; Turbellaria), Karaman (1993; Amphipoda), Argano (1979; Isopods), and Rivosecchi (1984; Diptera Ceratopogonidae). Calculated densities are finally referred to as number of individuals per square metre of sediment surface.

To provide information about the sediment chemical composition, subsamples of all sediments were analysed for macro- and microelements $(\mathrm{Si}, \mathrm{Al}, \mathrm{Fe}, \mathrm{Ti}, \mathrm{Ca}, \mathrm{K}$, $\mathrm{Mg}, \mathrm{Na}, \mathrm{P}, \mathrm{S}, \mathrm{Pb}, \mathrm{Zn}, \mathrm{Cu}, \mathrm{Ni}, \mathrm{Mn}, \mathrm{Cr}$ ) by X-Ray fluorescence spectrometry, and for $\mathrm{C}$ and $\mathrm{N}$ by means of a 
CHN Elemental Analyzer. The results of the chemical analyses are fully discussed in Baudo \& Beltrami (2001), and in this paper they are only mentioned to discuss the possible relationships with the benthic fauna distribution.

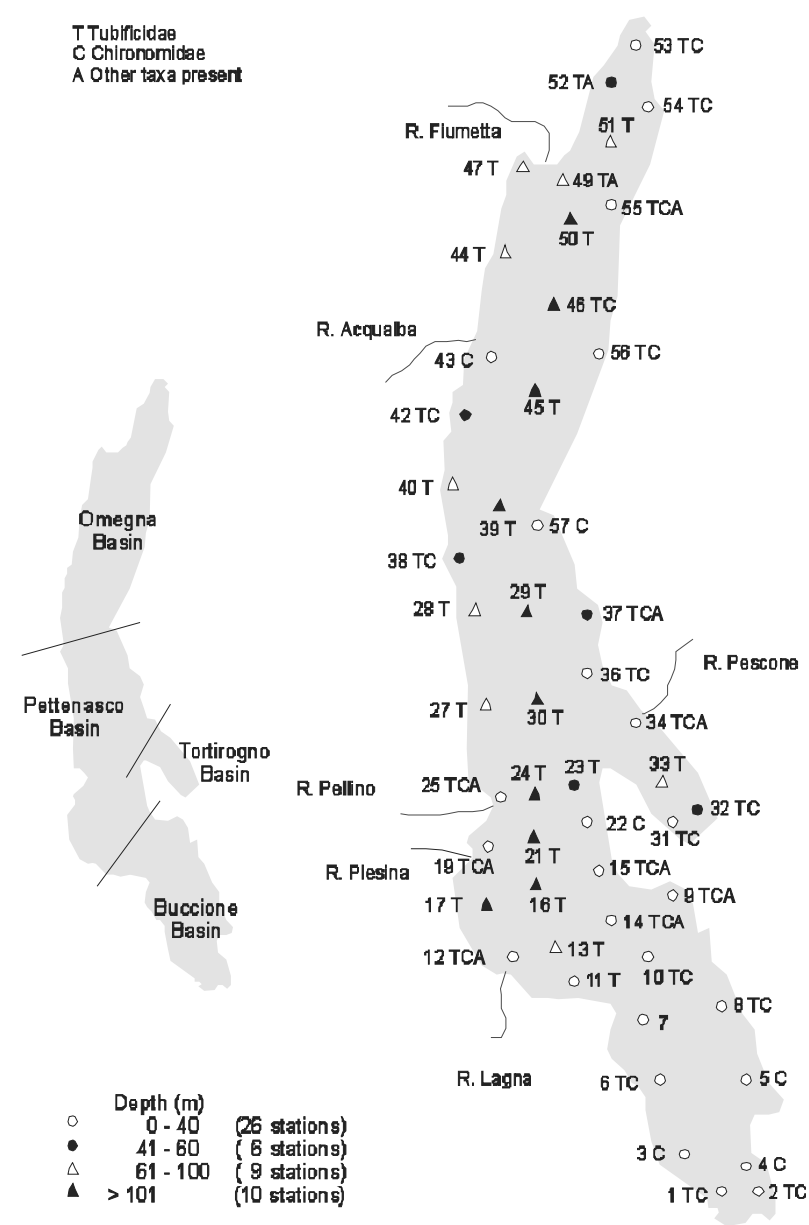

Fig. 1. Position of the sampling stations in the lake. Symbols correspond to bathymetric ranges. Letters indicate the presence of macrobenthic taxa.

\section{RESULTS AND DISCUSSION}

\subsection{Taxonomic considerations}

A total of 45 different taxa was identified from the benthic fauna of Lake Orta in 1996. However, the distribution of these taxa in the stations was markedly uneven. One station (B7) yielded no macrobenthos, 7 stations had only one taxon, 20 stations 2 taxa, only 6 stations had more than 5 taxa. Moreover, 18 taxa were recorded only at station T34, at the mouth of River Pescone in the Tortirogno sub-basin (Fig. 2).

In terms of abundance, the main taxonomic groups were Oligochaeta Tubificidae and Chironomidae. Tubificidae were present in 44 stations out of 51 (Tab. 1). By far the most common species was Tubifex tubifex, found in 33 stations (but only in 26 stations as adults). Other species of Tubificidae were Limnodrilus hoffmeisteri (adults in 8 stations and immatures in 5 stations), while Bothrioneurum vejdovskyanum, Branchiura sowerbyi e Aulodrilus pluriseta were found only in a single station each.

Chironomidae, belonging to 20 different taxa, were present in 29 stations. The most frequents were Chironomus thummi (22 stations) and Procladius sp. (17 stations). According to St. Louis (1993), acidified lakes often present a reduced number of Chironomidae species with regards to reference lakes, which host an average of 40 species. Furthermore, in acidified lakes a lower abundance of the Tribe Tanytarsini can be observed, whereas Chironomini, Tanypodinae, and Orthocladiinae seem to be less affected. In fact, in Lake Orta only 4 Tanytarsini, 10 Chironomini, 4 Tanypodinae, 3 Orthocladiinae, and 1 Prodiamesinae were observed. Therefore, the Chironomidae from Lake Orta possibly still reflect the parent community hosted by the sediments prior the liming, when the hypolimnetic $\mathrm{pH}$ was around 4.

Among the other taxonomic groups, the following were recorded: Turbellaria (7 stations, 2 species); Lumbriculidae ( 7 stations); Naididae (4 stations, 7 species); Crustacea (2 stations); Enchytraeidae (1 station); Ceratopogonidae (1 station).

\subsection{Depth distribution}

For most lakes, both the benthos abundance and the number of benthic taxa are highest in the mid-littoral zone and decrease as the depth increases (Brinkhurst 1974; Kajak 1987).

In Lake Orta too the distribution of the taxonomic groups was mainly determined by the depth gradient, as shown in figure 1 , where symbols of the stations indicate their bathymetric range. Stations deeper than $60 \mathrm{~m}$ were occupied only by mature and immature individuals of Tubifex tubifex, with only two exceptions (station O46: Chironomus thummi; and station O49: Limnodrilus hoffmeisteri, immature Limnodrilus and Lumbriculidae).

Stations less than $40 \mathrm{~m}$ deep were dominated by Chironomidae and Tubificidae, these latter, however, were absent in stations B3, B4, B5, P22, O43, P57.

In intermediate depth stations (range from -41 to -60 metres) Tubificidae were accompanied by Chironomidae, mainly Chironomus thummi, and occasionally by Procladius and Polypedilum.

These distributions obviously reflect the ecological characteristics of the different species. In fact, Tubificidae are often reported as the dominant species from littoral to profundal areas, whereas Chironomidae usually live in zones less than 10 metres deep, with only few species going down to $-30 \mathrm{~m}$. Moreover, in Lake Orta the stations with the higher richness of taxonomic groups are shallow and located near the main river inputs, which very likely act as colonising sources (Fig. 2). 


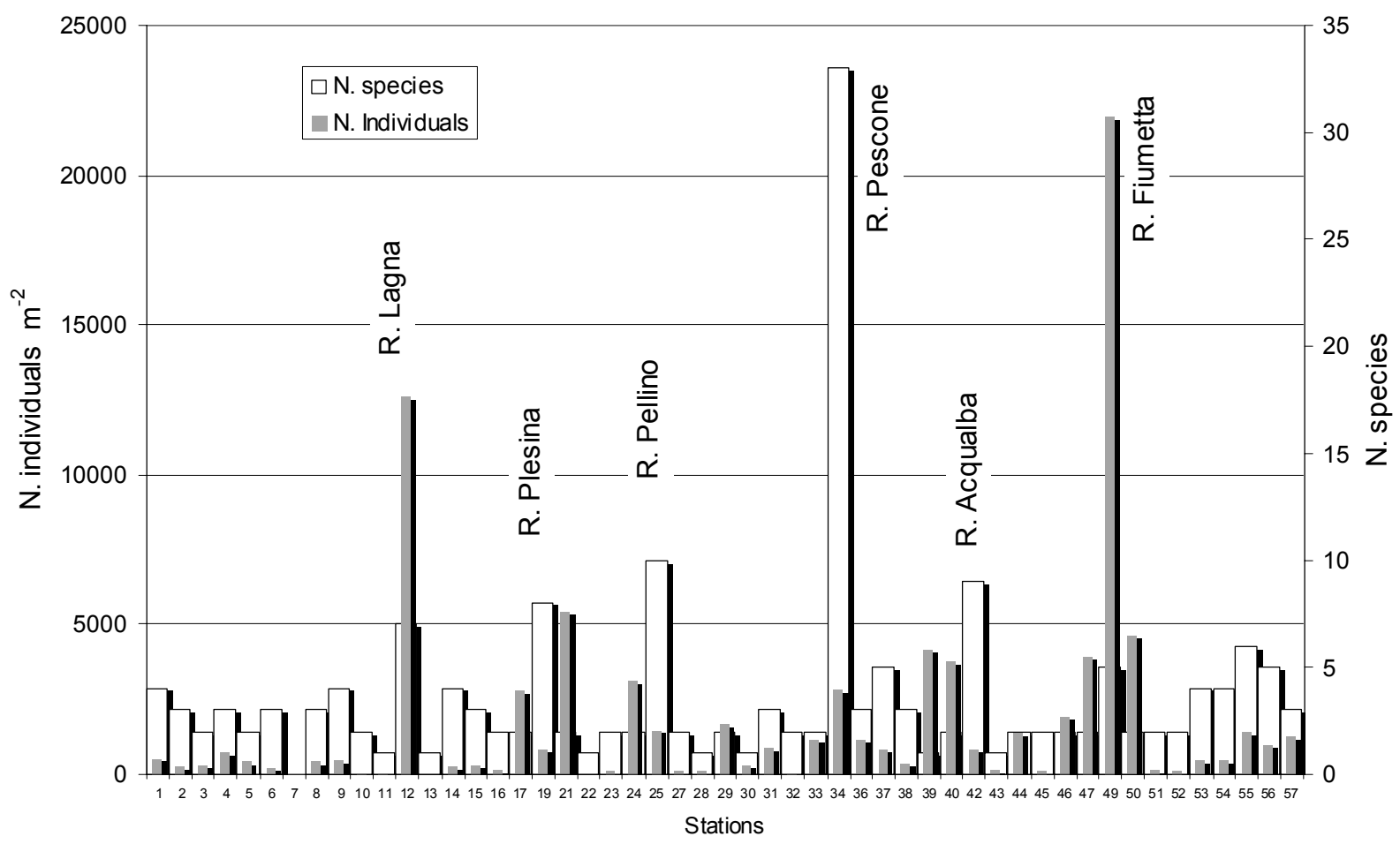

Fig. 2. Number of species and total abundance (ind. $\mathrm{m}^{-2}$ ) of benthic taxa in Lake Orta (51 stations sampled). Stations located near the main river outlets are indicated.

Tab. 1. Taxonomic richness and numerical abundances within the depth ranges of the lake.

\begin{tabular}{lcccc}
\hline Depth ranges $(\mathrm{m})$ & $<40$ & $41-60$ & $61-100$ & $>101$ \\
\hline Total number of taxa & 44 & 12 & 5 & 3 \\
Average $\mathrm{n}^{\circ}$ of taxa per station & 5 & 3.8 & 2.1 & 1.8 \\
Tubificidae $\left(\mathrm{n}^{\circ}\right.$ ind $\left.^{-1} \mathrm{~m}^{-2}\right)$ & 662 & 282 & 3587 & 2418 \\
Chironomidae $\left(\mathrm{n}^{\circ}\right.$ ind $\left.^{-1} \mathrm{~m}^{-2}\right)$ & 332 & 80 & 0 & 7.00 \\
Total macrobenthos $\left(\mathrm{n}^{\circ} \mathrm{ind}^{-1} \mathrm{~m}^{-2}\right)$ & 1086 & 369 & 3614 & 2425 \\
\hline
\end{tabular}

\subsection{Numerical abundance}

The average abundance over the 51 stations sampled in the lake was 40 ind $\mathrm{m}^{-2}$, with a minimum of 4 at stations P13 and P22 in the Pettenasco sub-basin, and a maximum of about 22,000 individuals at station $\mathrm{O} 49$, near the outlet of River Fiumetta, in the Omegna subbasin (Fig. 2).

As a whole, the total macrofauna abundances are much lower than densities commonly reported for unpolluted freshwater environments (105 ind $\mathrm{m}^{-2}$; Kajak 1988).

The most abundant group was that of Tubificidae (max 21,678 ind $\mathrm{m}^{-2}$ at station $\mathrm{O} 49$ ). In figure 3 two maps of benthos density are presented, the first for total individuals, the second one without inclusion of immature Tubificidae. The most densely populated areas were near the outlet of the rivers Fiumetta and Lagna. How- ever, by excluding immature Tubifex, areas of high abundance are revealed along the eastern bank, in the southern basin, and in front of River Pescone (station T34). This station is particularly rich in taxa, with large numbers of Naididae, Lumbriculidae, and genera of Chironomidae not present in other stations of the lake. Among the Tubificidae, the area of the River Lagna was dominated by mature Tubifex tubifex, while in the area facing River Fiumetta the immature Tubifex were particularly abundant.

The distributions of total Tubificidae (adults plus immature) and of total Chironomidae (the second group in terms of abundance) are shown in figure 4: the eastern bank and the southern basin, where the lowest densities of Tubificidae have been found, were dominated by Chironomidae.

Among the Chironomidae, the central and northern area were characterised by Procladius and the southern by Chironomus thummi (Fig. 5). 


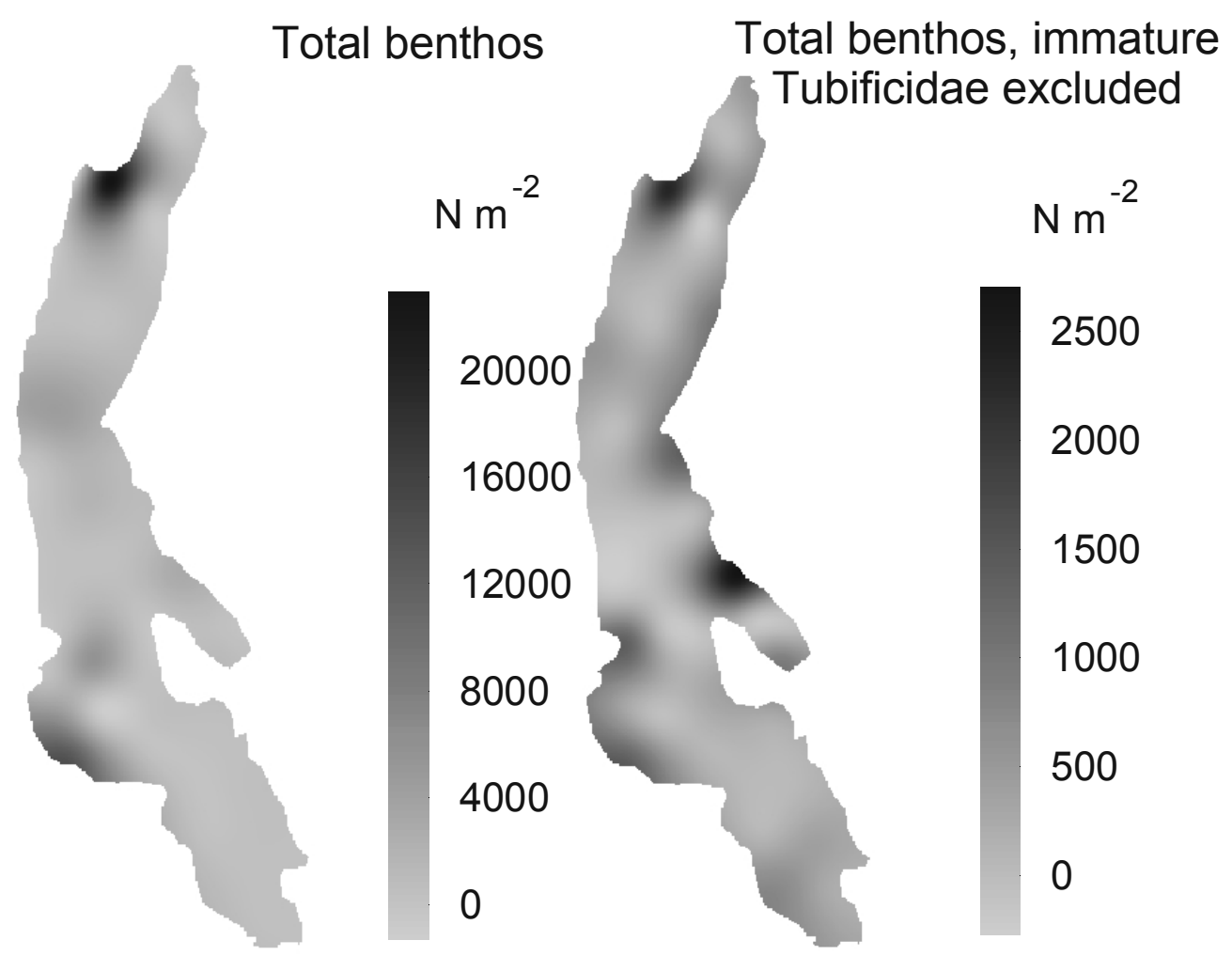

Fig. 3. Map of the total benthos abundance (left) and the same excluding immature Tubifex (right) in Lake Orta.

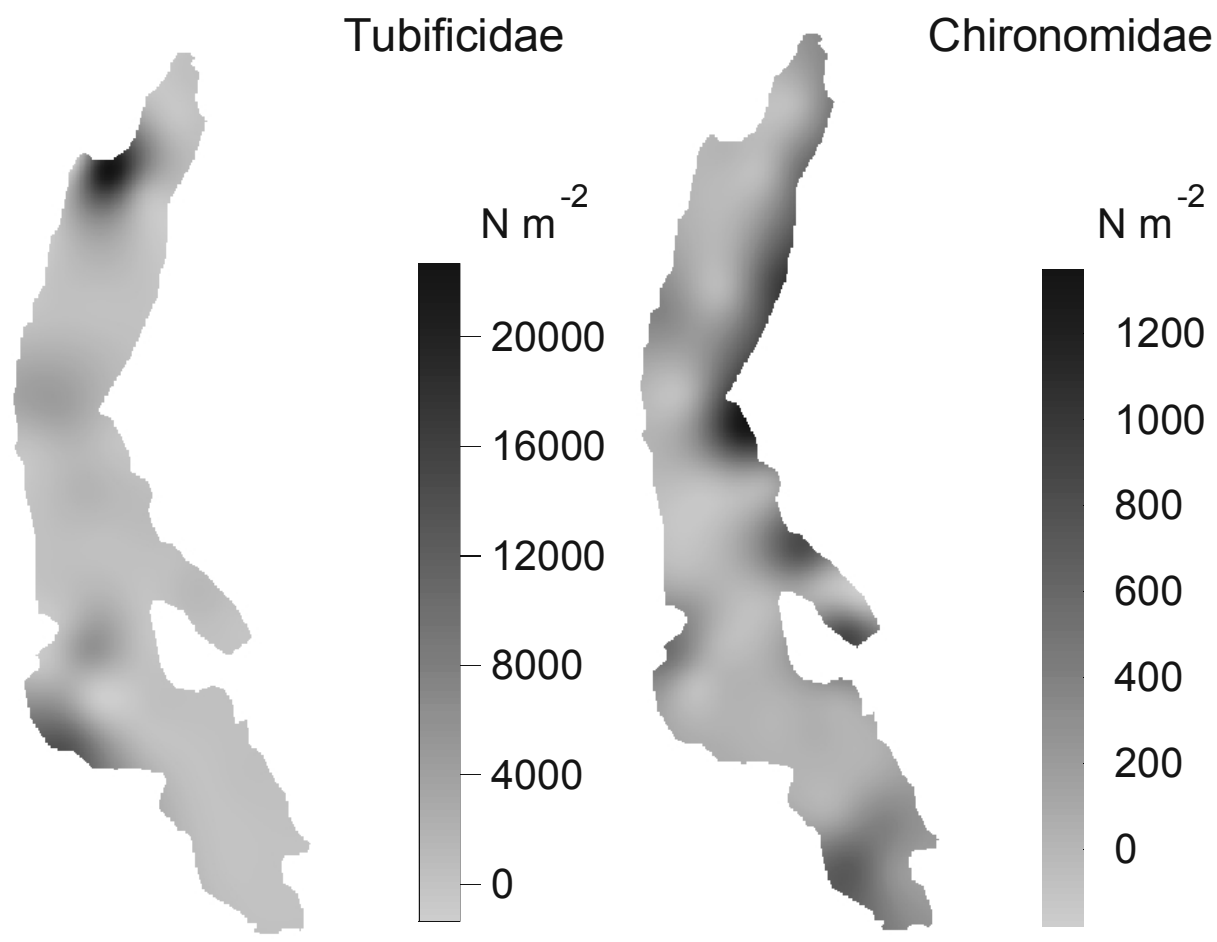

Fig. 4. Map of abundances of Tubificidae (left) and Chironomidae (right) in Lake Orta. 


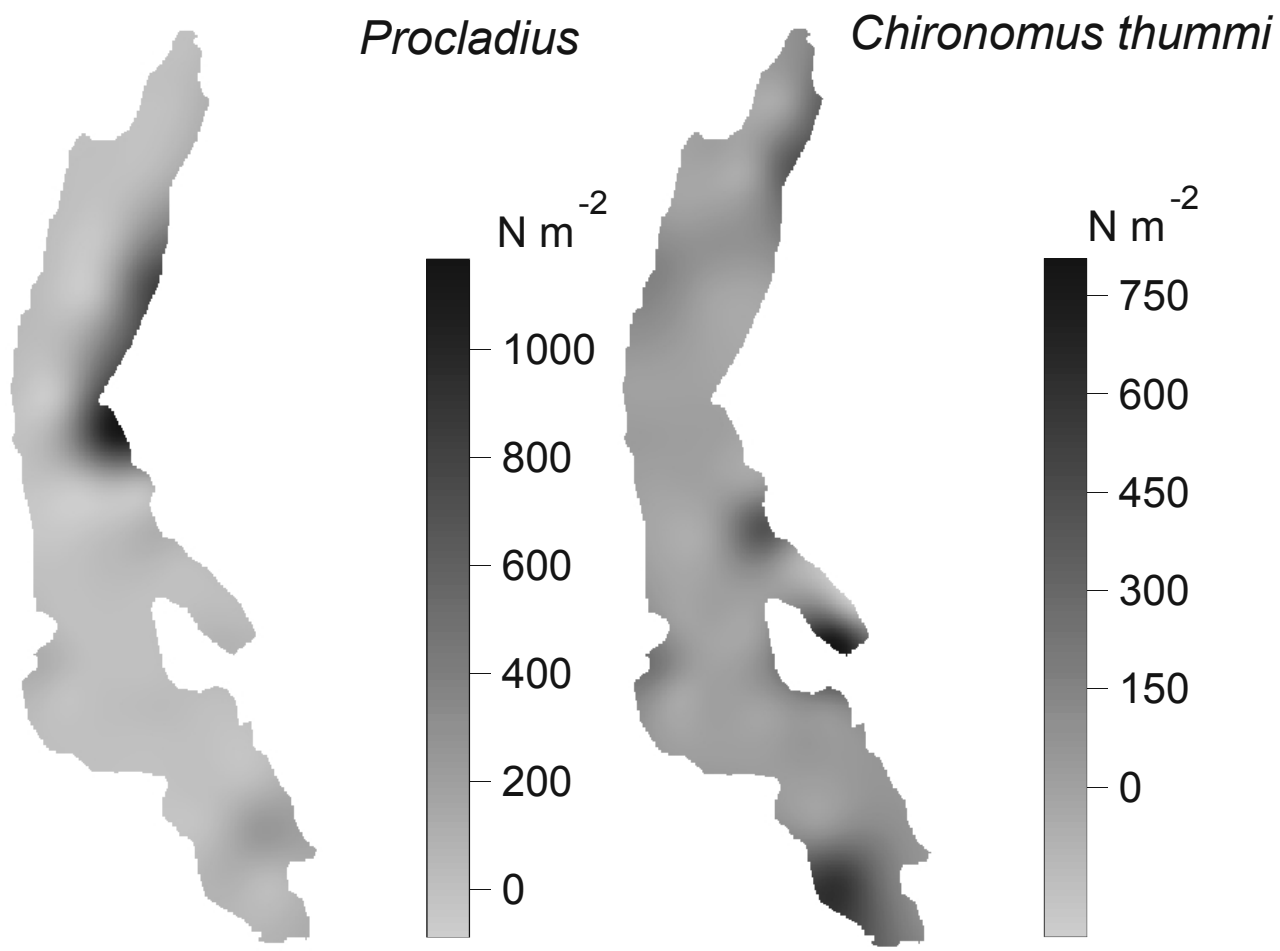

Fig. 5. Map of abundances of Procladius (left) and Chironomus thummi (right) in Lake Orta.

\subsection{Distribution of macrobenthos in relation to sediment chemistry}

As previously reported (La Point et al. 1984, Poulton et al. 1995), it is usually difficult to distinguish the effects on benthic communities due to metals from other factors, such as availability of organic matter as food. In fact, the statistical analysis of macrobenthos distribution as a function of the sediment chemical composition failed to provide any meaningful, significant relationship, probably because species number and benthos abundance are mainly controlled by the depth distribution and in many stations several species simply did not exist.

As a general trend, both the largest number of species and the highest benthos density were observed at low to intermediate levels of nutrients $(\mathrm{P}, \mathrm{C}, \mathrm{N})$, suggesting the obvious relationship with food availability (Kajak 1988), and no further increase in benthos abundance when the nutrient concentration exceed the benthos requirement.

The abundances of the main groups of organisms, Tubificidae and Chironomidae, seem also fairly insensitive to the concentrations of potentially toxic elements, such as $\mathrm{Pb}, \mathrm{Cu}$ and $\mathrm{Cr}$. In figure 6 , the lack of correlation between abundances and copper concentration in the sediment is shown as an example. Similar results were obtained with $\mathrm{Pb}, \mathrm{Cr}, \mathrm{Mn}, \mathrm{Fe}$, Ti. However, a negative statistical correlation with $\mathrm{Pb}$ concentrations was detected for Limnodrilus, Tubifex tubifex, Heterotrissocladius; with $\mathrm{Cu}$ for Dugesia tigrina, Heterotrissocladius, Paratendipes, Polypedilum breviantennatum, with $\mathrm{Cr}$ for Dugesia tigrina, Lumbriculidae, Heterotrissocladius, Paratendipes, Polypedilum breviantennatum, and Demycriptochironomus.

On the other hand, in general the taxa number decreases when the concentration of metals increases. More specifically, a high number of taxa were present at low levels of the mobile elements Fe, Mn and S.

\section{CONCLUSION}

As already mentioned, the distribution of the macrobenthos in Lake Orta was strongly related to depth, both in quantitative and qualitative terms. The taxa identified were all present within the depth of $25 \mathrm{~m}$, with the exception of Polypedilum laetum, found only at $-48 \mathrm{~m}$ and not at shallower stations. Furthermore, it can be stressed that 17 species were exclusively found at station $\mathrm{T} 34$ at the depth of $25 \mathrm{~m}$. Nevertheless, if this station were not taken into account, 25 taxa out of 28 would be represented within $24 \mathrm{~m}$ of depth.

All but one taxa were present in the stations shallower than $40 \mathrm{~m}$ (Tab. 1). Beyond 40 metres down to 60 $\mathrm{m}$ only 11 of these same taxa were still found. At depths over sixty metres only a small number of taxa were able to colonise the bottom. The species richness, expressed 
as the average number of taxa per station, was very low and decreased with depth.
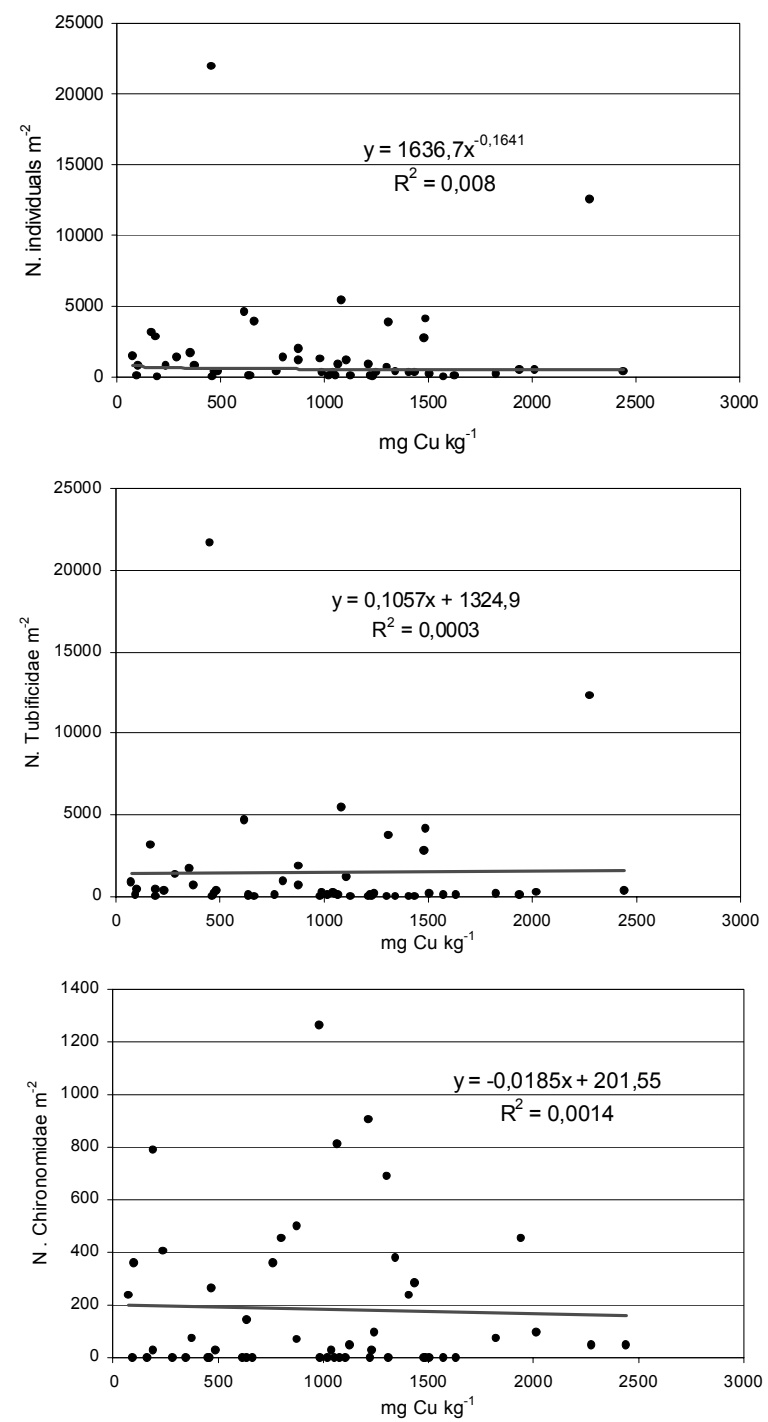

Fig. 6. Correlations between total number of individuals, Tubificidae and Chironomidae with copper concentration in the sediment.

In contrast, the density of individuals per square metre within the lake sediments was mainly dependent on the distribution of Tubificidae, that were particularly abundant in the deepest stations, beyond $60 \mathrm{~m}$ (probably favoured by the lack of competitors).

With reference to previous investigations, it can be noted that a species of Tubificidae, Spirosperma ferox, surely present in the past and disappeared at the onset of pollution (Bonacina et al. 1986), is still lacking from Lake Orta sediment after liming. Furthermore, Oligochaetae density is lower than that observed in 1993 and 1994 (De Margaritis 1994; Nocentini et al. 2000) in Buccione basin. As noted by Eriksson et al. (1983), Raddum et al. (1986), and Keller et al. (1990), the de- layed colonisation of sediments by Oligochaetae may be due to the chemical conditions of sediments and/or water.

Metals concentrations in the sediments of the lake actually largely exceed the level known to have probable effects on organisms: for instance, the Canadian Sediment Guidelines for the Protection of Aquatic Life suggest, as Probable Effect Levels for freshwater sediments, the values of $90 \mathrm{mg} \mathrm{kg}^{-1}$ for $\mathrm{Cr}, 197$ for $\mathrm{Cu}, 91.3$ for $\mathrm{Pb}$, and 315 for $\mathrm{Zn}$. The corresponding mean values for Lake Orta sediments are (Baudo \& Beltrami, 2001): $825 \mathrm{mg} \mathrm{kg}^{-1}$ for $\mathrm{Cr}$; 997 for $\mathrm{Cu}$; 305 for $\mathrm{Pb}$; 381 for $\mathrm{Zn}$. Considering that the maximum values are far more higher $\left(2877 \mathrm{mg} \mathrm{kg}^{-1}\right.$ for $\mathrm{Cr}, 2440$ for $\mathrm{Cu}, 660$ for $\mathrm{Pb}$, and 1004 for $\mathrm{Zn}$ ), it cannot be excluded that these metals may be responsible for the poor species diversity of the benthic fauna.

To test this hypothesis, according to the procedure described by Ingersoll et al. (1996), several Sediment Effect Concentrations (SECs) have been calculated (Tab. 2) for the three most represented taxa in Lake Orta, namely Tubifex tubifex, Chironomus thummi, and Procladius sp.

Assuming that the absence of one species in a station is due to the presence of a metal $(\mathrm{Cr}, \mathrm{Cu}, \mathrm{Pb}, \mathrm{Zn}$, or $\mathrm{Ni})$ in toxic concentrations for that species, and that its presence means that no toxic levels are reached, first the mean values $\left(\mathrm{mg} \mathrm{kg}^{-1}\right)$ for "non toxic" stations is calculated. Then, the concentrations in the "toxic" stations are sorted in an ascending order, and the lower 10 percentile (ERL, Effect Range Low) and 50 percentile (ERM, Effect Range Median) are calculated. In addition, the 50 percentile and 85 percentile of the sorted "non toxic" samples are assumed to indicate the No Effect Range Median (NERM) and the No Effect Range High (NERH). The geometric mean between ERL and NERM thus provides the Threshold Effect Level (TEL), and the geometric mean between ERM and NERH the Probable Effect Level (PEL). Finally, the No Effect Concentration (NEC) is calculated as the highest concentration of the metal in the "not toxic" sediments.

Comparing the actual data set with the calculated SECs, less than one third of the samples have been correctly classified as toxic (that is, they actually exceeded the calculated SEC and no animals were present). However, for most samples either they would have been classified as toxic, but still hosted some animals (false positive), or the metal concentrations were below the SEC, but no animals were present (false negative). This means that this analysis fails the acceptable criteria (at least $60 \%$ of the samples must be correctly classified), and therefore the absence of that species in some stations cannot be surely assumed as due to a "toxic" effect for the investigated metals.

Obviously, this approach tests independently the different metals, hence cannot exclude cumulative and/or synergistic effects. 
Tab. 2. Calculated Sediment Effect Concentrations $\left(\mathrm{mg} \mathrm{kg}^{-1}\right)$ for the most frequent species (Not Toxic, mean values for "non toxic" stations; ERL, Effect Range Low; ERM, Effect Range Median; NERM, No Effect Range Median; NERH, No Effect Range High; TEL, Threshold Effect Level; PEL, Probable Effect Level; NEC, No Effect Concentration).

\begin{tabular}{|c|c|c|c|c|c|c|c|c|}
\hline & Not Toxic & ERL & ERM & NERM & NERH & TEL & PEL & NEC \\
\hline \multicolumn{9}{|l|}{$\mathrm{Cr}$} \\
\hline Tubifex tubifex & 781 & 812 & 986 & 483 & 738 & 626 & 853 & 775 \\
\hline Chironomus gr. thummi & 906 & 955 & 1137 & 557 & 802 & 729 & 955 & 887 \\
\hline Procladius & 773 & 803 & 986 & 426 & 726 & 585 & 846 & 765 \\
\hline \multicolumn{9}{|l|}{$\mathrm{Cu}$} \\
\hline Tubifex tubifex & 839 & 987 & 1301 & 412 & 642 & 638 & 914 & 802 \\
\hline Chironomus gr. thummi & 1090 & 1216 & 1457 & 617 & 1011 & 866 & 1213 & 1080 \\
\hline Procladius & 897 & 1036 & 1307 & 457 & 750 & 688 & 990 & 874 \\
\hline \multicolumn{9}{|l|}{$\mathrm{Pb}$} \\
\hline Tubifex tubifex & 256 & 277 & 374 & 123 & 222 & 184 & 288 & 253 \\
\hline Chironomus gr. thummi & 363 & 385 & 459 & 253 & 308 & 312 & 376 & 360 \\
\hline Procladius & 308 & 327 & 435 & 221 & 289 & 269 & 354 & 297 \\
\hline \multicolumn{9}{|l|}{$\mathrm{Zn}$} \\
\hline Tubifex tubifex & 379 & 386 & 458 & 294 & 367 & 337 & 410 & 379 \\
\hline Chironomus gr. thummi & 410 & 418 & 517 & 328 & 382 & 370 & 444 & 401 \\
\hline Procladius & 364 & 374 & 421 & 246 & 345 & 303 & 381 & 363 \\
\hline \multicolumn{9}{|l|}{$\mathrm{Ni}$} \\
\hline Tubifex tubifex & 104 & 109 & 119 & 90 & 100 & 99 & 109 & 104 \\
\hline Chironomus gr. thummi & 111 & 114 & 123 & 90 & 103 & 101 & 113 & 110 \\
\hline Procladius & 104 & 109 & 119 & 90 & 100 & 99 & 109 & 104 \\
\hline
\end{tabular}

In any case, the calculated SECs seem to support the hypothesis of an adaptation of Orta benthos to metals. These values, in fact, are much higher than the proposed U.S. EPA, Region V, Guidelines for Classifying Sediments (Giesy \& Hoke 1990): according to these Guidelines, Lake Orta sediments should actually be classified as "heavily polluted" $\left(\mathrm{Cr}>75 \mathrm{mg} \mathrm{kg}^{-1} ; \mathrm{Cu}>50 \mathrm{mg} \mathrm{kg}^{-1}\right.$; $\left.\mathrm{Pb}>60 \mathrm{mg} \mathrm{kg}^{-1} ; \mathrm{Zn}>200 \mathrm{mg} \mathrm{kg}^{-1} ; \mathrm{Ni}>50 \mathrm{mg} \mathrm{kg}^{-1}\right)$.

The small number of taxa present in the lake confirms that the environment is very stressed. The few species that can survive here must have developed a strong resistance against many factors of stress, including high concentrations of heavy metals in the sediments. In fact, it is known that tolerant populations may develop in time as a result of chronic exposure to metal contaminated sediments (Krantzberg \& Stokes 1989; Poulton et al. 1995). This would explain why, in the shallow reaches of the lake, Chironomidae show a good potential for recolonisation, irrespective of the levels of sediment contamination.

However, albeit this study shows that benthos fauna is actively colonising Lake Orta bottom, spreading from river mouths, in 1996 the benthic community cannot be considered fully organised: for instance, whole groups of organisms, such as Mollusca, are still completely absent.

Therefore, further studies are needed to verify if and when the benthic fauna of Lake Orta will completely recover from decades of pollution.

\section{REFERENCES}

Argano, R. 1979. Isopodi (Crustacea Isopoda). Guide per il riconoscimento delle specie animali delle acque interne italiane. 5. CNR, P.F. "Promozione della qualità dell'ambiente", ACQUA/1/43: 62 pp.

Ballaré, G., E. Bielli, G. Fornara \& P. Masseroni. 1992. Qualità e utilizzo delle acque litorali del Lago d'Orta. In: Calderoni, A. \& R. de Bernardi (Eds), Atti Conv.: Orta, un lago da salvare: le fasi del suo recupero. Orta, 9-10 Aprile 1990. Documenta Ist. ital. Idrobiol, 38: 83-94.

Baudo, R. \& M. Beltrami. 2001. Chemical composition of Lake Orta sediments. J. Limnol., 60(2): 213-236.

Bonacina, C. 2001. Lake Orta: the undermining of an ecosystem. J. Limnol., 60(1): 53-59.

Bonacina, C., G. Bonomi \& R. Mosello. 1986. Notes on the present recovery of Lake Orta: an acid, industrially polluted, deep lake in North Italy. Mem. Ist. ital. Idrobiol., 44: $97-115$.

Bonacina, C., G. Bonomi \& C. Monti. 1986. Oligochaete cocoon remains as evidence of past lake pollution. Hydrobiologia, 143: 395-400.

Bonacina, C., G. Bonomi, L. Barbanti, R. Mosello \& D. Ruggiu. 1988. Recovery of an industrially acidified, ammonium and heavy metals polluted lake (Lake Orta, N. Italy), due to the adoption of treatment plants. Verh. int. Ver. Limnol., 23: 535-544.

Brinkhurst, R.O. 1974. The Benthos of Lakes. Macmillan Press: $190 \mathrm{pp}$.

Brinkhurst, R.O. \& B.G. Jamieson. 1971. Aquatic Oligochaeta of the World. Oliver \& Boyd, Edinburgh: $860 \mathrm{pp}$.

Calderoni, A. \& G.A. Tartari. 2001. Evolution of the water chemistry of Lake Orta after liming. J. Limnol., 60(1): 6978.

Calderoni, A., R. Mosello \& A. Quirci. 1991. Chemical response of Lake Orta (Northern Italy) to liming. Arch. Hydrobiol., 122: 421-439.

Cattaneo, A. 1992.The anthropogenically stressed periphyton of Lake Orta, Italy. Hydrobiologia, 234: 11-121.

Colosi, A. 1924. Dendrocelum lacteum (Müller) nel Lago d'Orta. Natura, 15(1): 37-38.

Corbella, C., V. Tonolli \& L. Tonolli. 1958. I sedimenti del Lago d'Orta testimoni di una disastrosa polluzione cuproammoniacale. Mem. Ist. Ital. Idrobiol., 10: 9-50. 
De Margaritis, G. 1994. Indagine sulle prime fasi di ripopolamento del Lago d'Orta (Bacino di Buccione) da parte della fauna macrobentonica dopo il risanamento del lago mediante l'intervento di "liming". Thesis, Univ. Pavia: 115 pp.

Eriksson, F., E. Hornstrom, P. Mossberg \& P. Nyberg. 1983. Ecological effects of lime treatment of acidified lakes and rivers in Sweden. Hydrobiologia, 101: 145-164.

Ferrarese, U. 1983. Chironomidi, 3 (Diptera Chironomidae: Tanypodinae). Guide per il riconoscimento delle specie animali delle acque interne italiane. 26. CNR, P.F. "Promozione della qualità dell'ambiente", ACQUA/1/204: $67 \mathrm{pp}$.

Giesy, J.P. \& R.A. Hoke. 1990. Freshwater Sediment Quality Criteria: Toxicity Bioassessment. In: R. Baudo, J.P. Giesy \& H. Muntau (Eds), Sediments: Chemistry and Toxicity of In-Place Pollutants. Lewis, Chelsea, MI: 265-348.

Ingersoll, C.G., P.S. Haverland, E.L. Brunson, T.J. Canfield, F.J. Dwyer, C.E. Henke, N.E. Kemble, D.R. Mount \& R.G. Fox. 1996. Calculation and Evaluation of Sediment Effect Concentrations for the Amphipod Hyalella azteca and the Midge Chironomus riparius. J. Great Lakes Res., 22: 602-623.

Kajak Z. 1987. Determinants of maximum biomass of benthic Chironomidae, Diptera. Entomol. Scand. Suppl. 1: 303308.

Kajak Z. 1988. Considerations on benthos abundance in freshwaters, its factors and mechanisms. Int. Revue ges. Hydrobiol., 73: 5-19.

Karaman, G.S. 1993. Crustacea: Amphipoda di acqua dolce. Fauna d'Italia, 31: 337 pp.

Keller, W., L.A. Molot, R.W. Griffiths \& N.D. Yan. 1990 Changes in the Zoobenthos Community of Acidified Bowland Lake after Whole-Lake Neutralization and Lake Trout (Salvelinus namaycush) Reintroduction. Can. J. Fish. aquat. Sci., 47: 440-445.

Krantzberg, G. \& P.M. Stokes. 1989. Metal regulation, tolerance, and body burdens in the larvae of the genus Chironomus. Can. J. Fish. aquat. Sci., 46: 389-398.

La Point, T.W., S.M. Melancon \& M.K. Morris. 1984. Relationships among observed metal concentration, criteria, and benthic community structural responses in 15 streams. J. Wat. Pollut. Contr. Fed., 56: 1030-1038.

Monti, R. 1930. La graduale estinzione della vita nel Lago d'Orta. Rend. R. Ist. Lomb. Sc. Lett., 63: 3-22.

Moretti, G.P. 1954a. La distribuzione dei Tricotteri lungo il litorale del Lago d'Orta. Mem. Ist. ital. Idrobiol., 8: $257-$ 270.

Moretti, G.P. 1954b. Il limnobio neritico dei Tricotteri a testimonianza dell'attuale situazione biologica del Lago d'Orta. Boll. Soc. Eustachiana, 47: 59-117.
Nocentini, A.M. 1985. Chironomidi, 4 (Diptera Chironomidae: Chironomidae, larve). Guide per il riconoscimento delle specie animali delle acque interne italiane. 29. CNR, P.F. "Promozione della qualità dell'ambiente", ACQUA/ 1/233: 187 pp.

Nocentini, A.M., A. Boggero, G. De Margaritis \& M. Gianatti. 2001. First phase of macroinvertebrate repopulation of Lake Orta (Buccione Basin) after liming. J. Limnol., 60(1): 110-126.

Oioli, G.F. 1969. Ricerche sulla fauna litorale del Lago d'Orta. Tesi di Laurea, Fac. di Scienze, Univ. Milano, Anno Accademico 1968-1969: 140 pp.

Parona, C. 1880. Prime ricerche intorno ai protisti del Lago d'Orta. Boll. Scientifico, Pavia, 2(1): 17-26.

Poulton, B.C., D.P. Monda, D.F. Woodward, M.L. Wildhaber \& W.G. Brumbaugh. 1995. Relations between benthic community structure and metals concentrations in aquatic macroinvertebrates: Clark Fork River, Montana. J. Freshwat. Ecol., 10: 277-293.

Raddum, G.G., P. Brettum, D. Matzow, J.P. Nillsen, A. Skov, T. Sveälv \& R.F. Wright. 1986. Liming the acid Lake Hovvatn, Norway: a hole-ecosystem study. Water, Air \& Soil Pollution, 31: 721-763.

Reynoldson, T.B. 1978. A key to the species of freshwater Triclads. Freshwat. Biol. Ass. Sci. Publ., 23.

Rivosecchi, L. 1984. Ditteri (Diptera). Guide per il riconoscimento delle specie animali delle acque interne italiane. 28. CNR, P.F. Promozione della qualità dell'ambiente, ACQUA/1/206: 177 pp.

Rossaro, B. 1982. Chironomidi, 2 (Diptera: Chironomidae: Orthocladiinae). Guide per il riconoscimento delle specie animali delle acque interne italiane. 16. CNR, P.F. Promozione della qualità dell'ambiente, ACQUA/1/171: 76 pp.

Ruggiu, D. 1969. Benthic Ciliates in the profundal of Lake Orta (Northern Italy). Verh. int. Ver. Limnol, 17: 255-258.

Sperber, C. 1952. A guide for the determination of Europea Naididae. Zool. Bidrag. Fran Uppsala, 29: 45-78.

St. Louis, V.L. 1993. Element concentrations in Chironomids and their abundance in the littoral zone of acidified lakes in Northwestern Ontario. Can. J. Fish. aquat. Sci., 50: 953-963.

Wiederholm, T. 1983. Chironomidae of the Holarctic region. Keys and diagnoses. Part. 1. Larvae. Ent. Scand. Suppl., 19: $457 \mathrm{pp}$.

Wiederholm, T. 1986. Chironomidae of the Holarctic region. Keys and diagnoses. Part. 2. Pupae. Ent. Scand. Suppl., 28: 482 pp. 